\title{
PROCEDURAL AND SUBSTANTIVE JUDICIAL REVIEW OF THE RIGHT TO HEALTH IN BRAZIL ${ }^{1}$
}

\author{
RICARDO PERLINGEIRO, \\ Fluminense Federal University \\ (Rio de Janeiro, Brazil)
}

This text seeks to identify the objective and subjective aspects of rights to an existential minimum in health care, based on international parameters which, because they are restricted to the internal scope of a nation, depend on a constitutional basis and on comprehensible facts, the demonstration of which should be the responsibility of the national administrative authority. Regarding the judicial review of the minimum right to healthcare, this paper points out that it is a serious mistake to try to handle public health conflicts according to the typical judicial principles governing conflicts under private law, because that distorts the public health system, with judicial orders that depart from the universal access to health care and that are often impossible to comply with. The article concludes that the judicial review of administrative authorities in matters involving the right to health necessarily requires simultaneous judicial review of the corresponding administrative procedures.

Keywords: right to health; effective judicial protection; judicial review of healthcare policy; enforcement of judicial decisions against administrative authorities.

Recommended citation: Ricardo Perlingeiro, Procedural and Substantive Judicial Review of the Right to Health in Brazil, 2(1) BRICS LJ (2015).

\footnotetext{
Derived from the following events: 'Judicialização da Saúde' ('Judicial Review of Health Care Policies'), $4^{\text {th }}$ Brazilian Medical Law Conference in Brasília, Federal District, on August 28, 2013; 'Direito a Saúde e judicialização' ('Right to Health and Judicial Review'), Conference on the $25^{\text {th }}$ Anniversary of the Citizens' Constitution in Niterói on October 2013; 'Judicial Review of Health Care Policies,' $3^{\text {rd }}$ Brazilian Conference of the Humanities in Medicine of the Federal Medical Council, Salvador, on October 24, 2013; 'New Perspectives on Judicial Review of the Health Care Policies in Light of Law No. 12.401,' Bahian Conference on Judicial Review of Health Care Policies by the Court of Justice of Bahia, Salvador, on October 31, 2013.
} 


\section{Table of Contents}

\section{Scope of the Expression 'Judicial Review of Health Care' on the Contem- porary Scene}

2. New Approaches to the Proviso of the Possible and the Existential Minimum in Health Care Cases

\section{Judicial Review of the Right to an Existential Minimum}

4. Misunderstanding of the Distinction between Public Law and Private Law and Its Judicial Repercussions

\section{Final Considerations}

\section{Scope of the Expression 'Judicial Review of Health Care' on the Contemporary Scene}

The phenomenon of judicial review of health care, as it has become known in Brazil, is continuing to grow geometrically. ${ }^{2}$ It has specific characteristics that are worth pointing out by way of an introduction. The judicial claims commonly asserted in this context are not claims for compensation for damages; in most cases, they are complaints against a public authority's acts related to the supplying of medicines or other health goods and services. ${ }^{3}$ They are basically limited to conflicts originating from acts of the health care authorities or of individuals in the exercise of such public powers. ${ }^{4}$ They are essentially public-law conflicts, however, ${ }^{5}$ which cannot be resolved without constantly weighing public versus private interests.

Recent examples of judicial review of health care show that numerous doubts persist about how to respond effectively to judicial conflicts involving the right to health vis-à-vis the public authorities.

One such example can be found in the notice published on the website Consultor Jurídico on June 8, 2013:

2 A preliminary report developed by the CNJ (Conselho Nacional de Justiça (National Justice Council)) points out that there were 240,980 judicial actions related to public health rights in 2011 in the Brazilian state and federal courts (preliminary data on health care assistance data in the courts).

3 See Ricardo Perlingeiro, O princípio da isonomia na tutela judicial individual e coletiva, e em outros meios de solução de conflitos, junto ao SUS e aos planos privados de saúde, 5(10) R. Proc.-Geral Mun. Belo Horizonte $(\mathrm{RPGMBH})(2012)$, available at <http://ssrn.com/abstract=2241142> (accessed Aug. 5, 2015).

4 See Ricardo Perlingeiro, A tutela judicial do direito público à saúde no Brasil, 2012(41) Direito, Estado e Sociedade, available at <http://ssrn.com/abstract=2250121> (accessed Aug. 5, 2015).

Regarding the concept of public law based on acts of authority (hoheitliche Gewalt), see Hartmut Maurer, Derecho administrativo alemán (= 637 Doctrina Jurídica) 52 (Universidad Nacional Autónoma de México 2012). 
At an executive board meeting of the Regional Medical Council of Rio de Janeiro, doctors of the vacancy control centres of the state and municipal public hospital network reported situations of abuse of authority by judicial officials. Representatives of the Court of Justice of Rio de Janeiro are using court orders to force doctors to find vacancies for patients even when no such vacancy is available in the hospitals in the network. Professionals also complain of being pressured into transferring patients in serious condition to the beds of an intensive care unit. They claim that they are being coerced because they can be arrested if they don't carry out the order. Two doctors of the vacancy control centres of the state hospitals are faced with criminal prosecution for failing to comply with a court order. ${ }^{6}$

Here is another noteworthy report published on the website of the Regional Medical Council of Espírito Santo on July 31, 2013:

Today, 31 July, the Regional Medical Council of Espírito Santo (Conselho Regional de Medicina do Espírito Santo (CRM-ES)) filed a public civil action against the Emergency Care Unit of Guarapari for the poor conditions of the unit and, as the principal complaint, for having delivered babies in the facility. According to Aloízio Faria de Souza, the Chairman of the CRM-ES, the Emergency Care Unit is not supposed to deliver babies or perform surgery. The lawsuit has been docketed by the Federal Civil Court of Vitória. Tomorrow, 1 August, the CRM-ES will file another public civil action, likewise at the Federal Civil Court of Vitória, against Hospital São Lucas. 'The conditions at the hospital are atrocious, with patients in serious condition "hospitalized" in the hallways. We hope that the Judiciary will require the State Government to make resources available to solve this serious problem. Avoidable deaths are part of the daily routine. It is necessary to put a stop to this situation, it's like being in a war zone,' complained the Chairman of the CRM-ES.

\section{New Approaches to the Proviso of the Possible and the Existential Minimum in Health Care Cases}

According to Law No. 12.401 of April 28, 2011, ${ }^{8}$ recasting Law No. 8.080 of September 19, 1990, comprehensive health care assistance consists of dispensing

6 Judicialização da saúde: Médicos denunciam abusos da Justiça do RJ, Consultor Jurídico (Jun. 8, 2013), <http://www.conjur.com.br/2013-jun-08/medicos-regulam-vagas-leitos-denunciam-abuso-justicarj> (accessed Aug. 5, 2015).

7 Ação Civil Pública contra PA de Guarapari e Hospital São Lucas, Conselho regional de medicina do estado do Espírito Santo (CRM-ES) (Jul. 31, 2013), <http://www.crmes.org.br/index.php?option=com content\&view $=$ article\&id=21021 $>$ (accessed Aug. 5, 2015).

8 Lei N ${ }^{\circ}$ 12.401, de 28 de abril de 2011, D.O.U. de 29.04.2011, at <http://www.planalto.gov.br/ccivil_03/_ Ato2011-2014/2011/Lei/L12401.htm> (accessed Aug. 5, 2015) (regulating therapeutic assistance and 
medicines and health products prescribed by the therapeutic guidelines defined in the clinical protocol for the disease or health problem to be treated and falling within the range of therapies for home care, outpatient or hospital treatment that are included in the tables drawn up by the federal director of the SUS, and performed in Brazil at one of the SUS's own health facilities or at others affiliated with the SUS or under contract. ${ }^{9}$

It is therefore apparent that the Law No. 12.401/2011 is general and delegates to the administrative authorities the task of defining the limits of the comprehensive right to health by stipulating that comprehensive health care assistance consists in such medicines, products and therapies as are indicated in the administrative regulations. ${ }^{10}$ The lawmakers should be less generous in that respect, however: the administrative authorities should not have such a broad authorization to decide which health services are obligatory, especially in the case of non-essential services, because it creates a risk of violating not only the prerogative of the drafters of the budgetary laws to allocate the public budget ${ }^{11}$ but also the very principle of the supremacy of the Rule of Law. ${ }^{12}$ Declaring social services to be obligatory should be the result of a prior democratic decision-making process expressed by society itself through legislators. An interpretation more consistent with the principle of the Rule of Law and with the proportionality requirement would be that the Law No. 12.401/2011 authorizes the administrative authority to declare as obligatory only such health services as are essential to a dignified existence. ${ }^{13}$

That does not mean, however, that any judicial claim that goes beyond the right to a minimum should be rejected. It is firmly established in Brazil that the right to

the incorporation of technologies into health care within the scope of the Brazilian Unified Public Health System (Sistema Único de Saúde) [hereinafter SUS]).

9 Article 19-M of Law No. 8.080 of September 19, 1990 (as formulated in Law No. 12.401/2011).

10 According to Art. 19-Q of Law No. 8.080/1990,' 't t] ine incorporation, exclusion or modification by the SUS of new medicines, products and procedures, as well as the formation or modification of the clinical protocol or therapeutic guidelines are powers assigned to the Ministry of Health with the advice of the National Commission of Incorporation of Technologies into the SUS!

11 According to Maurer, supra n. 5, at 121, it is not fully compatible with the principle of parliamentary democracy to allow administrative authorities to allocate the budget in such a way as to determine social rights without specifying the beneficiaries, the service, etc.

12 For more about the principle of the supremacy of the Rule of Law applicable to social rights, see Maurer, supra n. 5, at 114-28.

13 The right to the existential minimum should be anchored in law (see Federal Constitutional Court of Germany (Bundesverfassungsgericht (BVerfG)), Judgment of February 9, 2010 (BVerfGE 125, 175 (Rn. 136, 138), at <http://www.bundesverfassungsgericht.de/entscheidungen/ls20100209_1bvl000109. html $>$ (accessed Aug. 5, 2015))). Although the ideal would be more detailed analysis by the legislators, it is a fact that claims for the essential health care could easily fall into the exceptions to the principle of the Rule of Law (see Maurer, supra n. 5, at 122), so long as it is justifiable, for example as may happen with unexpected increases in claims caused by an epidemic or with technological innovations capable of curing a serious illness that was formerly incurable. 
health is a fundamental right, meaning that it is based on the Constitution, ${ }^{14}$ on the International Covenant on Economic, Social and Cultural Rights ${ }^{15}$ [hereinafter ICESCR] and on the Additional Protocol of San Salvador to the Inter-American Human Rights Convention (IHRC). ${ }^{16}$ With that in mind, since the fundamental right to health protection is broader than the right to a minimum of health care, the constitutional jurisdiction is available for claims for services beyond the limits of the authorization granted to the administrative authorities by Law No. 12.401/2011; in the case of a right to an essential health service, the claim will depend on judicial review of the abusive action or omission of the administrative authority, also known as 'administrative jurisdiction.'

At this point, it would helpful for us to review the concepts of the 'proviso of the possible' ('Vorbehalt des Möglichen') and of the 'existential minimum' ('Existenzminimum') which have been enshrined in Brazilian legal doctrine and case law under the acknowledged influence of the judicial precedents of the German Federal Constitutional Court. ${ }^{17}$

The proviso of the possible does not refer to a shortage of material or financial resources, nor should it be confused with a simple lack of public budget allocations. In fact, the proviso of the possible is intrinsically related to the legislator's prerogative to choose which social benefits will be considered a priority for funding, without implying any limitation or restrictions or existing enforceable subjective rights. The proviso of the possible is therefore inconceivable in cases involving the existential minimum or established statutory rights. In such cases, the margin of discretion of the legislators, including the drafters of budget laws, is zero, since to admit otherwise would be an offence to the principle of the Rule of Law. In fact, the proviso of the

14 Article 196 of the Constitution of the Federal Republic of Brazil of October 5, 1988 (Constituição da República Federativa do Brasil de 5 de outubro de 1988, D.O.U. 191-A de 05.10.1988), at <https:// www.planalto.gov.br/ccivil_03/constituicao/constituicao.htm> (accessed Aug. 5, 2015)) [hereinafter Constitution].

15 International Covenant on Economic, Social and Cultural Rights, Dec. 16, 1966, Art. 12, S. Treaty Doc. No. 95-19, 993 U.N.T.S. 3, 6 I.L.M. 360 (1967), at <http://www.ohchr. org/en/professionalinterest/pages/ cescr.aspx> (accessed Mar. 7, 2015) (ratified by Brazil on January 24, 1992 (Decreto $N^{\circ} 591$, de 6 de julho de 1992, D.O.U. de 07.7.1992, at <http://www.planalto.gov.br/ccivil_03/decreto/1990-1994/D0591.htm> (accessed Aug. 5, 2015))); see also General Comment No. 14: The Right to the Highest Attainable Standard of Health (Art. 12), U.N. ESCOR, Comm. on Econ., Soc. \& Cult. Rts., 22 ${ }^{\text {nd }}$ Sess., U.N. Doc. E/C.12/2000/4 (2000), at <http://www.refworld.org/docid/4538838d0.html> (accessed Aug. 5, 2015).

16 Additional Protocol to the American Convention on Human Rights in the Area of Economic, Social and Cultural Rights (Protocol of San Salvador), Nov. 17, 1988, Art. 10, O.A.S.T.S. No. 69, 28 I.L.M. 156 (1989), at <http://www.oas.org/juridico/english/treaties/a-52.html> (accessed Aug. 5, 2015).

17 See Ricardo Perlingeiro, Ė a reserva do possível um limite à intervenção jurisdicional nas políticas públicas sociais? / Does the Vorbehalt des Möglichen (the Proviso of the Possible) Limit Judicial Intervention in Social Public Policies?, 1(2) Revista de Direito Administrativo Contemporâneo (ReDAC) (2013), available at $<$ http://ssrn.com/abstract=2343965> (accessed Aug. 5, 2015) [hereinafter Perlingeiro, $\dot{E}$ a reserva do possivel um limite]. 
possible can only be used to deny such rights as exceed a claim for the existential minimum and are not yet anchored in a law that provides for their enforcement in court. ${ }^{18}$

It is no easy task to reach a proper understanding of the existential minimum, which may be associated with the weighing of subjective versus objective factors.

According to a recent precedent of the German Federal Constitutional Court in 2010, citizens have the right to demand the material prerequisites indispensable to their physical existence (food, clothing, household articles, housing, heating, sanitation and health) and at least a minimum of participation in social, cultural and political life, because human beings, as such, are necessarily integrated into social relationships. Thus, according to that same judicial decision, the minimum should be adapted to the level of development of the community in question and its current lifestyle, subject to constant updating, which constitutes the only room for manoeuvring provided by law..$^{19}$

As far as the objective content of the existential minimum is concerned, the instrumental and substantive aspects of the rights are invoked. ${ }^{20}$

Procedural rights are intended to ensure the practical realization of substantive rights; the same approach has been known to be applied with respect to fundamental rights, where the juncture between fundamental rights, organization and procedure is known as due process of fundamental rights, which is often considered the only way of producing results in compliance with such fundamental rights. ${ }^{21}$ From the standpoint of administrative law, effective judicial protection and administrative procedure are the citizen's main defences against the administrative authorities; public policies may be inserted into the same context. Regarding the prior assertion of a procedural right as a prerequisite for enforcing a substantive right against the

18 Perlingeiro, Ė a reserva do possível um limite, supra $\mathrm{n} .17$.

19 See BVerfGE 125, 175, supra n. 13.

20 See Ricardo Perlingeiro, Os cuidados de saúde dos idosos entre as limitações orçamentárias e o direito a um mínimo existencial / Health Care for the Elderly: Between the Budget Constraints and the Right to an Existential Minimum, 15(1) R. Dir. sanit. (2014), available at <http://www.revistas.usp.br/rdisan/article/ view/82808/85763> (accessed Aug. 5, 2015) doi:10.11606/issn.2316-9044.v15i1p83-118 [hereinafter Perlingeiro, Os cuidados de saúde dos idosos].

21 See Robert Alexy, Teoria dos direitos fundamentais 470 (Virgílio A. da Silva, trans.) (Malheiros 2008) (citing: Peter Häberle, Grundrechte im Leistungsstaat, in Wolfgang Martens et al., Grundrechte im Leistungsstaat. Die Dogmatik des Verwaltungsrechts vor den Gegenwartsaufgaben der Verwaltung. Berichte und Diskussionen auf der Tagung der Vereinigung der Deutschen Staatsrechtslehrer in Regensburg vom 29. September bis 2. Oktober 1971 (= 30 Veröffentlichungen der Vereinigung der Deutschen Staatsrechtslehrer (VVDStRL)) 43, 49 ff. (De Gruyter 1972), available at <http://www. degruyter.com/viewbooktoc/product/56448> (accessed Aug. 5, 2015); Konrad Hesse, Bestand und Bedeutung der Grundrechte in der Bundesrepublik Deutschland, 5 Europäische Grundrechte-Zeitschrift (EuGRZ) 427 (1978)). Alexy refers to 'fundamental rights as procedural guarantees', associating them with reproduction and conceptualization of a development found in the precedents of the Federal Constitutional Court (id. at 472). 
public authorities, legal scholars point out that 'material rights must enter into procedure, and fundamental rights must be enforced through procedure.'22

Internationally, it can be inferred that countries have certain minimum duties with respect to both procedural rights and substantive rights to health. Regarding procedural rights, I am referring to essential health policies; the substantive rights concern the essential medicines and health goods and services. ${ }^{23}$

According to the Committee on Economic, Social and Cultural Rights [hereinafter CESCR], Art. 12 of the ICESCR requires States to adopt appropriate legislative, administrative, budgetary, judicial or other steps to ensure the full realization of the right to health. If, on the one hand, each State has a margin of discretion to determine which measures are best suited to dealing with specific circumstances, on the other, the ICESCR clearly imposes an obligation on each State to take steps that are necessary in order to ensure that everyone has access to health facilities, goods and services and can attain the highest possible standard of physical and mental health. ${ }^{24}$

The following elements are considered indispensable for the minimum international standard of access to health care procedures:

a) availability. Functioning public health and health-care facilities, goods and services, as well as programmes, have to be available in sufficient quantity within the State party;

b) accessibility. Health facilities, goods and services have to be accessible to everyone without discrimination, within the jurisdiction of the State party;

(i) non-discrimination: health facilities, goods and services must be accessible to all, especially the most vulnerable or marginalized sections of the population, in law and in fact, without discrimination on any of the prohibited grounds;

(ii) physical accessibility: health facilities, goods and services must be within safe physical reach for all sections of the population, especially vulnerable or marginalized groups, such as ethnic minorities and indigenous populations, women, children, adolescents, older persons, persons with disabilities and persons with HIV/AIDS;

(iii) economic accessibility (affordability): health facilities, goods and services must be affordable for all;

(iv) information accessibility: accessibility includes the right to seek, receive and impart information and ideas concerning health issues. However, accessibility of information should not impair the right to have personal health data treated with confidentiality;

c) acceptability. All health facilities, goods and services must be respectful of medical ethics and culturally appropriate, i.e. respectful of the culture of individuals,

22 See Hans J. Wolff et al., 1 Direito administrativo 255, 490 (António F. de Sousa, trans.) (Fundação Calouste Gulbenkian 2006); see also Maurer, supra n. 5, at 479.

23 See Perlingeiro, Os cuidados de saúde dos idosos, supra n. 20.

24 See General Comment No. 14, supra n. 15. 
minorities, peoples and communities, sensitive to gender and life-cycle requirements, as well as being designed to respect confidentiality and improve the health status of those concerned;

d) quality. As well as being culturally acceptable, health facilities, goods and services must also be scientifically and medically appropriate and of good quality. ${ }^{25}$

Regarding substantive rights to health, according to the CESCR, despite any restrictions on resources, certain obligations have an immediate effect, such as the duty to guarantee at least a minimum level of access to the essential material elements of the right to health, like supplying essential medicines as well as child and maternal health services. ${ }^{26}$

The above-cited General Comment No. 14 of the CESCR is particularly relevant to access to essential medicines. On that subject, the CESCR declares that the medical services referred to in Art. 12(2)(d) of the ICESCR include the supplying of essential drugs 'as defined by the WHO Action Programme on Essential Drugs.' According to the WHO's latest definition, '[e]ssential medicines are those that satisfy the priority health care needs of the population. Essential medicines are selected with due regard to disease prevalence, evidence on efficacy and safety, and comparative cost-effectiveness. ${ }^{27}$

The objective minimum international parameters should therefore be taken as the point of reference when deciding whether or not to allow restrictions or extensions of the guarantees to the right to health on the national level, depending on the possibilities of the State and the needs of the individual, i.e. the subject side of the existential minimum. In any case, restrictions to adjust the existential minimum to the actual situation in the country in question should be accompanied by a clear statement of justifications by the public authority, which is responsible for the task of explaining the other public expenditures transparently and, above all, understandably, using a reliable and consistent method of calculation. ${ }^{28}$

\section{Judicial Review of the Right to an Existential Minimum}

Judicial claims to receive medicines or health services (substantive rights) are generally paid for out of the financial resources allocated to the appropriate

25 General Comment No. 14, supra n. 15.

26 Id.

27 See Essential Medicines, World Health Organization (WHO), <http://www.who.int/medicines/services/ essmedicines_def/en/> (accessed Aug. 5, 2015).

28 Regarding the need for the public authority to provide clear justifications and understandable criteria of calculation, see BVerfGE 125, 175, supra n. 13; see also Karl-Peter Sommermann, Soziale Rechte in Stufen: Überwindung einer alten Debatte?, in Rechtsstaatlichkeit, Freiheit und soziale Rechte in der Europäischen Union: Deidesheimer Kolloquium 2012 zu Ehren von Detlef Merten anlässlich seines 75. Geburtstages ( $=80$ Wissenschaftliche Abhandlungen und Reden zur Philosophie, Politik und Geistesgeschichte) 107 (Christian Calliess et al., eds.) (Duncker \& Humblot 2014). 
heading of the general public health service budget (procedural rights). Thus, since an individual judicial action of this type affects a number of users of the same public health service, it means that granting the corresponding claim should be conditional on the administrative authority's prior restructuring of the distribution of available resources to the successive requests presented to that authority extrajudicially. ${ }^{29}$

That is why the 'justiciability' of rights to health care requires advance or even, when necessary, simultaneous judicial review, ${ }_{1}^{30}$ of the corresponding procedural right. The court needs to review not only the material claims to the medicine, health product or service in question but, primarily, the claim to be eligible for the administrative procedure or guarantees for obtaining the health product or service (even if only incidentally), in such a way as to confer greater magnitude and power on the judicial protection. That will enable the court to ensure equality among all users of the public health service. ${ }^{31}$

Regarding the incorporation of new technologies provided for in Law No. 12.401/2011 (Arts. 19-M(I) and (II)), a health product or service can fall within the scope of the concept of comprehensive care until it has undergone the specific administrative procedure of being incorporated into the SUS. That clearly means that the right to a new medicine, health product or service is linked to a procedural right. Moreover, since the above-mentioned process of incorporation into the SUS falls within the area of authority of a federal administrative authority, the National Committee of Incorporation of Technologies (Comissão Nacional de Incorporação de Tecnologias (CONITEC)), the authority to decide a related court case would belong to the Federal Justice System; ${ }_{i}^{32}$ and the same can be said of the medicines, health products or services subject to registration with the National Health Surveillance Agency (Agência Nacional de Vigilância Sanitária (ANVISA)).

29 See Perlingeiro, Os cuidados de saúde dos idosos, supra n. 20.

30 'However, despite the obvious importance of prior procedural structuring of the administrative authorities, such as, among other things, the necessity of equality among all concerned, whether judicial claimants or not, the fact is that such organization is an obligation interna corporis of the administrative authority and must not, per se, undermine the substantive right itself or effective judicial protection, particularly where the right to the existential minimum is concerned' (Perlingeiro, È a reserva do possível um limite, supra n. 17, at 182-83).

31 See Perlingeiro, Os cuidados de saúde dos idosos, supra n. 20. In a lawsuit in which it was alleged that the medicines Alpha-2a or Alpha-2b Pegylated Interferon and Ribavirine were necessary for the treatment of chronic hepatitis $C$, one of the judges of the Superior Court of Justice (Superior Tribunal de Justiça) held that '[a]ccording to democratic principles . . . the State does not have a duty to provide an individual service unless it would be viable to give the same treatment to all the individuals in the same situation under conditions of equality' (Opinion of Judge Teori Albino Zavascki in the Writ of Mandamus Proceeding (STJ, Recurso em Mandado de Segurança, RMS No. 24.197 - PR (2007/0112500-5), Relator: Min. Luiz Fux, 04.05.2010, at <http://stj.jusbrasil.com. br/jurisprudencia/16825941/recurso-ordinario-em-mandado-de-seguranca-rms-24197-pr-20070112500-5/inteiro-teor-16825942> (accessed Aug. 5, 2015))).

32 See Art. 109(I) of the Constitution. 
However, even if the substantive rights are accepted as subordinate to procedural rights, that fact alone is insufficient to minimize the conflicts involving the 'justiciability' (eligibility for judicial review) of rights to health care, especially in the case of conflicts based on the insufficient financial resources of the government..$^{33} \mathrm{It}$ is easy to imagine that an administrative authority, despite having complied with the rules of procedure, including the budgetary rules, might end up without sufficient financial resources to meet the multiple, unexpected and urgent demands.

Consequently, from the financial point of view, the conflicts involving the rights to health care that are winding up in court can be examined from two different perspectives: one, as originating in the lack of sufficient budget resources, and the other originating in mismanagement by the administrative authority itself.

In the first case, if the right to an existential minimum and, in general, the rights to health care created by law were not sufficiently well anchored in the budget, ${ }^{34}$ which in and of itself would amount to a violation of the Rule of Law, that would provide an opportunity for judicial intervention through urgent judicial measures of enforcement of the judgements.

As already mentioned, the public budget is a decisive factor in ensuring a judicial system that is democratic in the distribution of social benefits, but only with respect to rights which, despite originating in the Constitution, depend on the law for enforcement. In fact, the public budget is not capable of nullifying the right to an existential minimum or social rights enshrined by law. ${ }^{35}$

In the second case, from the financial standpoint, the conflict may result from the conduct of the administrative authority, which, despite being allocated the budgetary resources, claims that it does not really have financial resources to meet the health care demands. Such situations of de facto depletion of resources also amount to a violation of the Rule of Law, which also calls for effective judicial protection against the public administrative authorities. ${ }^{36}$

33 See Perlingeiro, Os cuidados de saúde dos idosos, supra n. 20.

34 'A country's difficult financial situation does NOT absolve it from having to take action to realize the right to health' (The Right to Health: Fact Sheet No. 31, at 5 (Office of the United Nations High Commissioner for Human Rights (OHCHR); World Health Organization (WHO) 2008), available at <http://www.ohchr.org/Documents/Publications/Factsheet31.pdf> (accessed Aug. 5, 2015).

35 Alexy affirms that 'the principle of the legislators' authority over the budget is not unlimited. It is not an absolute principle. Individual rights may have greater weight than political-financial reasons' (Alexy, supra n. 21, at 512-13) and 'even the minimal fundamental social rights have an enormous impact, especially when many people need to exercise them. Yet that fact alone, considered in isolation, does not justify the conclusion that such minimal rights do not exist' (id. at 512). The German Federal Constitutional Court ruled that economic aspects cannot be taken into consideration in order to deny reimbursement to the insured of expenses on new medical treatments necessary to cure a life-threatening illness (BVerfGE 115, 25, at <http://www.bverfg.de/entscheidungen/ rs20051206_1bvr034798.html> (accessed Aug. 5, 2015)).

36 See Perlingeiro, Os cuidados de saúde dos idosos, supra n. 20. 
Thus, theoretically, the lack of budget resources is no obstacle to the judicial review of health care rights. ${ }^{37}$ However, since administrative authorities are bound to respect the letter of the law and have no independent means of direct interpretation and application of such laws to the Constitution, the lack of budget allocations may serve as a justification for failing to provide social services, which inevitably leads to judicial review. Besides that, given the lack of budget allocations and resources, enforcement of decisions would be difficult, because the expropriation of public assets and financial resources, in principle, is conditional on not doing harm to any public interest or essential service, which means that the court's jurisdiction over such cases is limited. ${ }^{38}$

For example, an individual judicial claim for hospitalization for treatment of a curable disease was presented to the public health system, which does not have sufficient funds to make up for the shortage of beds and doctors; unfortunately, that is a very common example in our country. ${ }^{39}$ It is unquestionable that the court should acknowledge the right in question; however, it would not make sense to enforce a judicial decision in favour of one claimant at the expense of another hospitalized patient with the same needs. The enforcement would require calling upon third parties, as by contracting for private beds, but even that depends on the availability of public financial resources available that are not earmarked for other essential services. ${ }^{40}$

In the enforcement of judicial decisions concerning the right to health against administrative authorities, the judicial expropriation of public assets is possible, in principle, under the following circumstances: a) public property that is not assigned a specific purpose, such as unused land, or public assets in general that have not been assigned a specific purpose, such as funds available from the collection of tax revenue; b) assets and financial resources allocated to a non-essential, accessory public service

37 Regarding the enforcement of judicial decisions against administrative authorities, see generally L'exécution des décisions des jurisdictions administratives: VIIII'me congrès de l'Association internationale des hautes juridictions administratives (Madrid, 2004), <http://www.aihja.org/images/users/1/files/2004 Congres_de_Madrid__Rapport_VIII_congres_VIII_vf.pdf?PHPSESSID=f83dg63dqj61 vokoep4kk44 fu1 $>$ (accessed Aug. 5, 2015).

In Brazil, the enforcement of judicial decisions against administrative authorities is generally permitted, except when contrary to the public interest (Law No. 12.016/2009, Art. 15; Law No. 8.437/1992, Art. 4, introductory paragraph and $\S 1$; Law No. 9.494/1997, Art. 1). Especially in the case of judgements against the administrative authorities to pay a certain sum, it is inappropriate to satisfy the claim by attaching assets available to the public administrative authority (Law No. 5.869/1973 (Code of Civil Procedure), Arts. 730 f.), except in the case of minor debts (Law No. 10.259/2001, Art. 17(2); and Law No. 12.153/2009, Art. 13(1)). Nevertheless, recent precedents have authorized the enforcement of debts of any amount (STF, STA No. 36-8, Relator: Min. Nelson Jobim, D.J.U. 27.09.2005, p. 6). For more on that issue, see STF, ARE No. 665707, Relator: Min. Luiz Fux, 19.11.2012, at <http://www.stf.jus.br/ portal/cms/verNoticiaDetalhe.asp?idConteudo=224106 $>$ (accessed Aug. 5, 2015).

40 See Perlingeiro, Os cuidados de saúde dos idosos, supra n. 20. 
of a type that is typically private, such as the costs of government media campaigns or the purchase of luxury cars for official purposes ${ }^{41} \mathrm{c}$ ) assets and financial resources earmarked for repayment of past debts, provided that they are not capable, in and of themselves, of disrupting the continuity of an essential public service.

\section{Misunderstanding of the Distinction between Public Law and Private Law and Its Judicial Repercussions}

It is not always easy to identify a conflict that is governed by public law and therefore allows for proper application of the corresponding principles. ${ }^{42}$ In Germany, for example, the responsibility for illegal administrative acts by the public authorities still falls under the jurisdiction of the ordinary courts, whereas the revocation of those same acts falls under the administrative jurisdiction. ${ }^{43}$ Such misunderstandings are particularly common in Brazil, where legal doctrine and jurisprudence have many reasons to distinguish public law from private law because of the unified jurisdiction (monist system of jurisdiction) and the laws of civil procedure applicable to publiclaw cases (except in certain passages, such as the doubled time allowance for enforcement of judgments, in which the criterion for application is the involvement of the administrative authorities rather than the nature of the conflict). ${ }^{44}$

In fact, there are various theories that indicate the difference between public law and private law; that distinction is debatable and controversial. ${ }^{45} \mathrm{It}$ is no longer appropriate to invoke the difference based exclusively on the subject: it is affirmed that private law regulates relationships between private citizens whereas public law is concerned with the State. That concept, the theory of the subject, has been modified by Hans Wolff's attribution theory (theory of imputation, theory of the excessive right).$^{46}$ According to Wolff's theory, norms that can be attributed only to

41 See generally: Juiz suspende publicidade oficial e concede dinheiro à saúde, Conversa Afiada (Jul. 31, 2013), <http://www.conversaafiada.com.br/pig/2013/07/31/juiz-suspende-publicidade-oficial-e-dadinheiro-a-saude/> (accessed Aug. 5, 2015); MPF/RR pede sequestro e bloqueio das contas do Estado de Roraima caso ordem judicial seja descumprida, Ministério Público Federal / Procuradoria da Republica em Roraima (Apr. 4, 2013), <http://www.prrr.mpf.mp.br/noticias/04-04-13-mpf-rr-pede-sequestro-ebloqueio-das-contas-do-estado-de-roraima-caso-nao-seja-comprovado-o-cumprimento-de-ordemjudicial/> (accessed Aug. 5, 2015).

42 Wolff et al., supra n. 22, at 263-64.

43 See Jacques Ziller, Modelli di responsabilità dell'amministrazione in alcuni ordinamenti europei, 2009(2) Dir. e soc.; see also Wolff et al., supra n. 22, at 264.

44 The Anglo-American legal system is not based on the distinction between public law and private law (Wolff et al., supra n. 22, at 267; Peter Cane, Administrative Law 4 ( $5^{\text {th }}$ ed., Oxford University Press 2011)) legal system from which the Brazilian monist judicial system originated.

45 See: Maurer, supra n. 5, at 50-52; Wolff et al., supra n. 22, at 264-67; Cane, supra n. 44, at 4-9; Jean Rivero \& Jean Waline, Droit administratif 1-5 (21 $1^{\text {st }}$ ed., Dalloz 2006).

46 Wolff et al., supra n. 22, at 267-86. 
the State or to another subject invested with authority (i.e. norms that are directed exclusively at the State or other subject invested with authority) belong to public law. In contrast, norms that correspond to any other subject are matters of private law. That is the theory that should prevail because it is connected with the various functions of public law and private law. ${ }^{47}$

In the administrative jurisdiction, the object of which is resolve public-law conflicts, a citizen seeks to enforce an individual interest through acts of a public authority; such acts fall into the category of administrative procedures, acts and decisions. In fact, the 'administrative' judge, in the sphere of public law, should not enforce a material interest without first taking such administrative acts into account; such judges are entitled to impose an obligation of the public administrative authorities that did not previously exist in the extrajudicial sphere; in other words, judicial review does not absolve the administrative authorities from the obligation to enforce claims solely through the existing procedures, especially in the case of social services (rights of participation).

A judicial claim for enforcement of a substantive right, vis-à-vis the public administrative authorities in a typical public-law situation, necessarily presupposes that there were errors or omissions in an administrative act: errors of form or of content, errors of law or of fact. In the specific case of errors of content of an administrative decision, the court brings about, indirectly, the materialization or realization of a substantive right or interest; in public law, this amounts to saying 'the realization of administrative decisions through material behaviours of the administrative authorities. ${ }^{\prime 48}$

47 According to attribution theory, the public / private law distinction may be exemplified by different cases of driving: public law is said to govern a case of official driving of a civil-defence or police car or even a first-aid or public service vehicle (e.g., ambulance, electrical utility repair vehicle), whereas private law would govern cases of driving an official vehicle in a normal situation for the transportation of public property (Maurer, supra n. 5, at 54). Another example of public law is the obligation to ensure access to health and provide health care, establishing health policies, administrative procedures for supplying health products and services; private law, on the other hand, is applicable to medical / hospital treatment per se, to the supplying of medicine with no connection with corresponding administrative procedures (on the difference between access to the public service and performance of the public service based on the effects of public law and private law, see Maurer, supra n. 5, at 57-58). Public law relates to any exclusive activity of the public administrative authorities or of an individual in the exercise of a public power; an activity that is not replacable by any individual. On the contrary, private law pertains to any activity capable of being exercised by an individual who is not invested with public authority. The simple supplying of a medicine or surgical procedure without relation to the prior administrative procedures that authorized them (provided access) is a question of private law; the liability for damages caused by a defective drug or surgical error, i.e. by an act that is not connected in terms of cause and effect with any act by an authority would be a question of private law that must be based on intentional misconduct or negligence. However, if the absence of the drug or medical procedure is directly related to administrative behaviours, such as a budget shortage or deficiencies in the selection procedure, then the case is governed by public law. For more about the two-phase theory (first chapter of public law, second chapter of private law), see Wolff et al., supra n. 22, at 282.

48 Material administrative behaviours are those aimed at a factual rather than legal result; they are not administrative acts, decisions or procedures (Maurer, supra n. 5, at 406). 
In this context, judicial decisions on public law cases either establish a legal fact or condemn the act of an authority; the realization of the interests acknowledged in such a decision is a logical corollary but enforcement is not necessary for the supplying of the corresponding asset or financial resources, which, in that respect, do not go beyond the mere factual materialization of judicially declared administrative behaviours; thus, a judicial order to the public administrative authorities would suffice with respect to the acknowledged behaviour. ${ }^{49}$ In fact, the whole structure regarding the enforcement of judicial decisions against public administrative authorities, expropriating the available public property, is inherent in conflicts involving legal relationships under private law, which are therefore eligible for a typical ordinary jurisdiction compatible with the principles of private law..$^{50}$ In such cases, the dispute itself does not involve public-law solutions, for example, when compensation for damages does not require prior administrative procedures. The public authorities, to the extent involved in the private domain, do not necessarily act by means of procedures, and the judicial claims may be direct or narrowly focused; in that respect, judicial enforcement is proportionate and capable of expropriating public property, merely being limited to the public interest.

In a public-law conflict, a difficulty might arise when the judge finds an error on the part of the public administrative authorities and rules in favour of the claimant but the public authorities fail to obey the court and do not supply the goods in question. When faced with such a defiant administrative omission, the natural approach would be, in the executive jurisdiction, to 'prosecute' by reviewing the administrative procedure leading up to the supplying of the relevant goods (administrative norm, budget, etc.). ${ }^{51}$ Since it is not possible to wait indefinitely, however, a viable alternative would be execution proceedings against the public administrative authorities on the model of a judicial resolution of a private-law conflict, while remaining aware of it limitations, which are disadvantageous to the claimant.

49 In Italy, in parallel with enforcement against the administrative authorities by an ordinary (civil) judge, it is worth mentioning the 'giudizio di ottemperanza', within the scope of the administrative jurisdiction, inherent in the enforcement of judicial decisions regarding administrative behaviours, which may even result in orders to pay compensation for damages (Giuseppina Mari, II giudizio di ottemperanza, in 2 II nuovo processo amministrativo 457 (Maria A. Sandulli, ed.) (Giuffrè 2013)). The enforcement of judgements against the administrative authorities delivered by civil judges only in exceptional cases adopts the form of the 'giudizio di ottemperanza,' when there are questions of public law in the enforcement phase (Marcello Clarich, XIV. L'esecuzione, Diritto processuale amministrativo ( 7 Corso di diritto amministrativo diretto da Sabino Cassese) 297, 302-03 (Aldo Sandulli, ed.) (2 $2^{\text {nd }}$ ed., Giuffrè 2013)).

50 Regarding the relationship between enforcement of judicial decisions against the public administrative authorities and their responsibility for public assets, see Alberto R. Ojeda, La ejecucion de creditos pecuniarios contra entes publicos 21 (Civitas 1993).

51 According to Ada Pellegrini Grinover, the judge would order the public administrative authorities to adapt the public budget in such a way as to pay its debt (see Ada Pellegrini Grinover, O controle jurisdicional de políticas públicas, in O controle jurisdicional de políticas públicas 138 (Ada Pellegrini Grinover \& Kazuo Watanabe, eds.) ( $2^{\text {nd }}$ ed., Forense 2013)). 
Similarly to relationships under private law, in which the enforcement of judgements against an individual cannot reach the inalienable goods of the debtor, in enforcement against public authorities it is not possible to expropriate public assets allocated to an essential activity; in other words, the public assets that are available are limited and finite. In public law, on the contrary, the creation of resources is theoretically admissible; the State is never considered to be insolvent. From that point of view, the individual would be protected by asserting his rights through the channels of public law, which is the only jurisdiction that could achieve the full realization of his claims. The ordinary jurisdiction (of private law) might prove detrimental to the individual because it treats him equally in relation to the public administrative authorities, ignoring the need to weigh private versus public interests.

In fact, it is inappropriate to try to resolve a public law conflict according to private law principles and vice vers $a_{1}^{.52}$ it would be inconsistent to make judicial claims for services of the State that are typical of public law based on the reasoning of private law. The unconditional search for the realization of an interest (in this case, protection of one's health), on the level of public law, must not flout the principles that govern the public administrative authorities, which include equal access to public goods and services.

In extreme cases, as when there is an imminent threat to the claimant's dignified existence, it is undoubtedly admissible to 'attach' public assets in order to satisfy the claimant (forced hospitalization, supplying of medicines or money to buy medicines) in the name of effective judicial protection of the Rule of Law. That will always be an imperfect and limited solution, however, because not all public assets can be expropriated (the line is drawn where it is necessary to protect the public interest and ensure the continuity of an essential social service). It would also be a partial solution because it benefits only the claimants and therefore violates the principle of equality. In public law, enforcement is therefore a solution that should be adopted only when strictly necessary (urgent judicial measures, danger in delay involving non-pecuniary rights).

In fact, it appears to be unavoidable for judicial review to examine administrative procedures (administrative norms, budgetary laws), even if only incidentally, which is a condition sine qua non for judicial review of the rights to health service vis-à-vis the public authorities, when the service essentially arises from a legal relationship under public law. The reluctance of public administrative authorities to comply with court orders in public-law cases, however, is symptomatic of a serious institutional imbalance, indicator of a weakened Rule of Law, which might have to be resolved on the political level.

\footnotetext{
52 See: Maurer, supra n. 5, at 53; Cane, supra n. 44, at 9.
} 


\section{Final Considerations}

Essential rights to health, from the standpoint of substantive and procedural rights, including public policies, should comply with the objective international baselines which, because they are reduced to the national level, should take the level of development of the relevant society into account, as well as the existing standard of living and actual needs of the individual in the specific case at issue.

The principle of effective judicial protection extends to urgent court measures and judicial enforcement, including vis-à-vis administrative authorities in healthcare. To admit otherwise, would be a serious departure from the Rule of Law.

On the one hand, the shortage of budgetary resources and funding is no obstacle to the enforceability of the right to health (which is not affected by the proviso of the possible). On the other hand, the enforcement of judgements against the public authorities must comply with the public interest (the need for continuity in essential social services), which often leaves the impression of a deficient judiciary, with widespread frustration concerning the effectiveness of social rights, which is blamed on the Judiciary, even though completely outside its control. In fact, the judicial expropriation of available public goods to satisfy individual claims is typical of jurisdiction over private law conflicts involving the public authorities and, in the field of public law, it is a solution that is not only inadequate but also imperfect because the available resources are finite and not all claims manage to satisfy their claims.

Exaggerated judicial review is a consequence of an insufficient public health system but, paradoxically, it has exacerbated that deficiency by fuelling the growing inequality among the judicial claimants versus non-claimants. This is so because, in most cases, judicial review of healthcare is treated as a private-law conflict, without paying proper attention to the administrative procedures, which are mainly intended to ensure universal access to the healthcare.

In fact, claims for medicine and healthcare goods and services should generally be exercised exclusively through the administrative procedures, although, in urgent cases, those claims and procedures are reviewed by the courts simultaneously or, at most, procedural parameters are considered purely incidentally.

In this context, it is also necessary to think about reinforcing the structure of such procedures through a de facto, independent and qualified extrajudicial system of administrative dispute resolution, with the primary objective of defending fundamental rights. Such a system, which would salvage the credibility of the healthcare authorities, is the only realistic way of reducing the conflicts inherent in the judicial review of healthcare. 


\section{References}

Alexy, Robert. Teoria dos direitos fundamentais 470, 472, 512-13 (Virgílio A. da Silva, trans.) (Malheiros 2008).

Cane, Peter. Administrative Law 4-9 $\left(5^{\text {th }}\right.$ ed., Oxford University Press 2011).

Clarich, Marcello. XIV. L'esecuzione, Diritto processuale amministrativo (= 7 Corso di diritto amministrativo diretto da Sabino Cassese) 297, 302-03 (Aldo Sandulli, ed.) ( $2^{\text {nd }}$ ed., Giuffrè 2013).

General Comment No. 14: The Right to the Highest Attainable Standard of Health (Art. 12), U.N. ESCOR, Comm. on Econ., Soc. \& Cult. Rts., $22^{\text {nd }}$ Sess., U.N. Doc. E/C.12/2000/4 (2000), at <http://www.refworld.org/docid/4538838d0.html> (accessed Aug. 5, 2015).

Häberle, Peter. Grundrechte im Leistungsstaat, in Wolfgang Martens et al., Grundrechte im Leistungsstaat. Die Dogmatik des Verwaltungsrechts vor den Gegenwartsaufgaben der Verwaltung. Berichte und Diskussionen auf der Tagung der Vereinigung der Deutschen Staatsrechtslehrer in Regensburg vom 29. September bis 2. Oktober 1971 (= 30 Veröffentlichungen der Vereinigung der Deutschen Staatsrechtslehrer (VVDStRL)) 43, $49 \mathrm{ff}$. (De Gruyter 1972), available at <http://www. degruyter.com/viewbooktoc/product/56448> (accessed Aug. 5, 2015).

Hesse, Konrad. Bestand und Bedeutung der Grundrechte in der Bundesrepublik Deutschland, 5 Europäische Grundrechte-Zeitschrift (EuGRZ) 427 (1978).

L'exécution des décisions des jurisdictions administratives: VIIIİme congrès de l'Association internationale des hautes juridictions administratives (Madrid, 2004), <http://www.aihja. org/images/users/1/files/2004_Congres_de_Madrid_Rapport_VIII_congres_VIII_vf .pdf?PHPSESSID=f83dg63dqj61 vokoep4kk44fu1> (accessed Aug. 5, 2015).

Mari, Giuseppina. II giudizio di ottemperanza, in 2 II nuovo processo amministrativo 457 (Maria A. Sandulli, ed.) (Giuffrè 2013).

Maurer, Hartmut. Derecho administrativo alemán (=637 Doctrina Jurídica) 50-54, 57-58, 114-28, 406, 479 (Universidad Nacional Autónoma de México 2012).

Ojeda, Alberto R. La ejecucion de creditos pecuniarios contra entes publicos 21 (Civitas 1993).

Pellegrini Grinover, Ada. O controle jurisdicional de políticas públicas, in O controle jurisdicional de políticas públicas 138 (Ada Pellegrini Grinover \& Kazuo Watanabe, eds.) ( $2^{\text {nd }}$ ed., Forense 2013).

Perlingeiro, Ricardo. A tutela judicial do direito público à saúde no Brasil, 2012(41) Direito, Estado e Sociedade, available at <http://ssrn.com/abstract=2250121> (accessed Aug. 5, 2015).

Perlingeiro, Ricardo. È a reserva do possível um limite à intervenção jurisdicional nas políticas públicas sociais? / Does the Vorbehalt des Möglichen (the Proviso of the Possible) Limit Judicial Intervention in Social Public Policies?, 1(2) Revista de Direito Administrativo Contemporâneo (ReDAC) 182-83 (2013), available at <http://ssrn. com/abstract $=2343965>$ (accessed Aug. 5, 2015). 
Perlingeiro, Ricardo. O princípio da isonomia na tutela judicial individual e coletiva, e em outros meios de solução de conflitos, junto ao SUS e aos planos privados de saúde, 5(10) R. Proc.-Geral Mun. Belo Horizonte (RPGMBH) (2012), available at <http://ssrn. com/abstract $=2241142>$ (accessed Aug. 5, 2015).

Perlingeiro, Ricardo. Os cuidados de saúde dos idosos entre as limitações orçamentárias e o direito a um mínimo existencial / Health Care for the Elderly: Between the Budget Constraints and the Right to an Existential Minimum, 15(1) R. Dir. sanit. (2014), available at <http://www.revistas.usp.br/rdisan/article/view/82808/85763> (accessed Aug. 5, 2015). doi:10.11606/issn.2316-9044.v15i1p83-118

Rivero, Jean, \& Waline, Jean. Droit administratif 1-5 (21 $1^{\text {st }}$ ed., Dalloz 2006).

Sommermann, Karl-Peter. Soziale Rechte in Stufen: Überwindung einer alten Debatte?, in Rechtsstaatlichkeit, Freiheit und soziale Rechte in der Europäischen Union: Deidesheimer Kolloquium 2012 zu Ehren von Detlef Merten anlässlich seines 75. Geburtstages ( $=80$ Wissenschaftliche Abhandlungen und Reden zur Philosophie, Politik und Geistesgeschichte) 107 (Christian Calliess et al., eds.) (Duncker \& Humblot 2014).

The Right to Health: Fact Sheet No. 31, at 5 (Office of the United Nations High Commissioner for Human Rights (OHCHR); World Health Organization (WHO) 2008), available at <http://www.ohchr.org/Documents/Publications/Factsheet31.pdf > (accessed Aug. 5, 2015).

Wolff, Hans J., et al. 1 Direito administrativo 255, 263-86, 490 (António F. de Sousa, trans.) (Fundação Calouste Gulbenkian 2006).

Ziller, Jacques. Modelli di responsabilità dell'amministrazione in alcuni ordinamenti europei, 2009(2) Dir. e soc.

\section{Information about the author}

Ricardo Perlingeiro (Rio de Janeiro, Brazil) - Full Professor at Law School, Fluminense Federal University, Federal Appellate Judge of the Regional Federal Court of the $2^{\text {nd }}$ Region (Rio de Janeiro) and Chairman of the Executive Committee of the National Council of Justice for the Monitoring and Settlement of Health Care Assistance Claims in the State of Rio de Janeiro (84 Rua Professor Hernani Melo, São Domingos, Niterói, Rio de Janeiro, 24210-130, Brasil; e-mail: perlingeiro@nupej. uff.br). 